\title{
Interactions between SAM and the 5' UTR mRNA of the sam1 gene regulate translation in $S$. pombe
}

\author{
XUHUI ZHANG, ${ }^{1}$ WENXIA SUN, ${ }^{1}$ DONGRONG CHEN, and ALASTAIR I.H. MURCHIE \\ Fudan University Pudong Medical Center, Pudong and Key Laboratory of Medical Epigenetics and Metabolism, Institute of Biomedical Sciences, \\ Shanghai Medical College, Fudan University, Shanghai 200032, China \\ Key Laboratory of Metabolism and Molecular Medicine, Ministry of Education, School of Basic Medical Sciences, Fudan University, \\ Shanghai 200032, China
}

\begin{abstract}
The $5^{\prime}$ untranslated region (5' UTR) of eukaryotic mRNA plays an important role in translation. Here we report the function of the 5' UTR mRNA of S-adenosylmethionine synthetase (sam1) in translational modulation in the presence of SAM in fission yeast Schizosaccharomyces pombe. Reporter assays, binding and chemical probing experiments, and mutational analysis show that the $5^{\prime}$ UTR mRNA of sam 1 binds to SAM to effect translation. Translational modulation is dependent on a tertiary structure transition in the RNA upon SAM binding. The characterization of such an RNA that is directly associated with an essential metabolic process in eukaryotes provides additional evidence that ligand binding by RNAs plays an important role in eukaryotic gene regulation.
\end{abstract}

Keywords: SAM; regulatory RNA; 5' UTR mRNA; sam1; regulation of translation initiation; Schizosaccharomyces pombe

\section{INTRODUCTION}

Translation in eukaryotes is a complex and dynamic process that involves the orderly and timely interplay of ribosomal subunits, mRNA, and eukaryotic initiation factors (elFs) in a coordinated manner (Sokabe and Fraser 2019). The eukaryotic translation is highly regulated at the point of initiation rather than at the elongation or termination phases. The $5^{\prime}$ untranslated regions (UTRs) of the mRNAs play important regulatory roles in the regulation of eukaryotic translational initiation (Jackson et al. 2010; Leppek et al. 2017). RNA molecules may fold into diverse tertiary structures that provide an additional level of control in translational initiation (Leppek et al. 2017). For example, a conserved putative pseudoknot in human interferonmRNA can activate the interferon-inducible protein kinase $\mathrm{R}(\mathrm{PKR})$ to regulate the translation of the interferon gene (Ben-Asouli et al. 2002); the mRNA of the mouse ubiquitin carboxyl-terminal hydrolase L1 (Uch/1) can be partially base-paired with its antisense RNA, and a repeat region of the Uchl1 mRNA $5^{\prime}$ UTR increases ribosome binding and translation through an undetermined mechanism (Carrieri et al. 2012); a stem-loop in the UTR mRNA of the iron storage and transporter proteins ferritin and ferro-

\footnotetext{
${ }^{1}$ These authors contributed equally to this work.

Corresponding authors: aihm@fudan.edu.cn, drchen@fudan. edu.cn

Article is online at http://www.rnajournal.org/cgi/doi/10.1261/rna. 072983.119.
}

portin serves as an iron binding RNA domain to regulate their translation initiation (Hentze et al. 1987; Gray and Hentze 1994; Muckenthaler et al. 1998, 2017); G-quadruplex tertiary structures in UTR RNAs may bind to proteins to repress translation (Schaeffer et al. 2001; Castets et al. 2005); specific RNA structures or sequence motifs serve as target RNA sequences for elongation initiation factors (elFs); higher ordered structured RNAs in the form of internal ribosomal entry sites (IRESs) in the 5'UTRs of the homeobox gene family regulate translation in response to stress (Xue et al. 2015). These independent studies suggest that the contribution of structured RNA mechanisms of translational regulation are diverse and comparatively unexplored. Genome-wide chemical probing of RNA has revealed cellular RNAs to be highly structured (Kertesz et al. 2010; Ding et al. 2014). Dynamic structural changes may correlate with potential regulatory RNA function (Rouskin et al. 2014; Mustoe et al. 2018; Tapsin et al. 2018).

In bacteria, mechanisms of transcriptional and translational attenuation through structured RNAs have been described since the 1980s (Yanofsky 1981; Stroynowski et al. 1982). Classes of UTR mRNAs described as riboswitches are also known to regulate bacterial transcription and

(c) 2020 Zhang et al. This article is distributed exclusively by the RNA Society for the first 12 months after the full-issue publication date (see http://rnajournal.cshlp.org/site/misc/terms.xhtml). After 12 months, it is available under a Creative Commons License (Attribution-NonCommercial 4.0 International), as described at http:// creativecommons.org/licenses/by-nc/4.0/. 
translation. Riboswitches, acting as biosensors, are ligandbinding noncoding regions of mRNAs that regulate the expression of downstream ligand related genes. Ligand binding to RNA causes conformational changes that directly control ligand related gene expression. Over 20 types of riboswitches have been identified by bioinformatics methods through sequence similarities. The ligands include metabolites such as purines, cofactors and their derivatives, amino acids, cations, anions, and antibiotics (Grundy and Henkin 2004; Vitreschak et al. 2004; Wickiser et al. 2005; Jia et al. 2013; Serganov and Nudler 2013). There are also classes of temperature sensing regulatory RNAs (Kortmann et al. 2011; Kortmann and Narberhaus 2012; Krajewski et al. 2014). S-Adenosyl-L-methionine (SAM) is an essential, metabolic ribonucleotide cofactor in all cells. SAM acts as the methyl group donor for methyltransferase enzymes and also provides the propylamine moiety for polyamine synthesis. Of the enzyme cofactors, only ATP exploits a greater variety of enzymes than SAM; therefore, there is a requirement for SAM levels inside the cell to be controlled (Cantoni 1975; Schubert et al. 2003; Loenen 2006). Six classes of SAM sensing riboswitches have been reported in bacteria. SAM-I riboswitches function at the transcriptional level by binding to SAM stabilizing terminator or antiterminator hairpins to inhibit or activate transcription (Winkler et al. 2003). SAM-II-IV riboswitches work at the level of translation to either repress or activate translation. Chemical probing experiments show that upon SAM binding, the mRNA undergoes a secondary structure transition that masks or unmasks ribosome-binding sites to repress or activate translation initiation (Winkler et al. 2003; Fuchs et al. 2006; Gilbert et al. 2008; Weinberg et al. 2008; Poiata et al. 2009; Mirihana Arachchilage et al. 2018). Despite extensive efforts, only one class of eukaryotic riboswitch has been identified through sequence homologies with a prokaryotic counterpart, the thiamine pyrophosphate (TPP) riboswitch in fungi, algae, and higher plants (Kubodera et al. 2003; Sudarsan et al. 2003). Unlike prokaryotic riboswitches that directly target transcription or translation, the eukaryotic TPP riboswitch controls gene expression by manipulating the selection of alternative splice-sites in premRNA (Bocobza et al. 2007; Cheah et al. 2007; Croft et al. 2007; Wachter et al. 2007). The identification of the TPP riboswitch in eukaryotes suggests that additional ligand sensing RNAs may have a role in the control of eukaryotic gene expression.

In prokaryotes, the effects of structured RNAs upon translational initiation are comparatively well understood (Serganov and Nudler 2013; Breaker 2018). Chemical probing and the available crystal structures of riboswitch RNAs demonstrate that ligand-dependent accessibility of the Shine-Dalgarno (SD) sequence on the mRNA determine translational initiation (Breaker 2018). In comparison, the mechanism of eukaryotic translation initiation in which structured mRNA has a regulatory role is much more complex, more diverse, and less likely to have common features (Ben-Asouli et al. 2002; Carrieri et al. 2012; Leppek et al. 2017). To further our understanding of the roles of structured RNAs in eukaryotic translation initiation, further studies are required. Here we show that the $5^{\prime}$ UTR of sam 1 regulates translation initiation upon SAM binding. Reporter assays suggest that the $5^{\prime}$ UTR of sam 1 mediates repression of translation in the presence of SAM precursor methionine. The RNA secondary and tertiary structure was investigated by dimethyl sulfate (DMS) and $\mathrm{OsO}_{4}$ chemical probing. Mutational analysis and $\mathrm{OsO}_{4}$ chemical probing showed that the tertiary structure transition upon SAM binding contributes to the regulation of translation initiation. This study provides biochemical evidence for a role in SAM metabolism for specific SAM binding to the $5^{\prime}$ UTR of sam 1, leading to downstream effects on the expression of the sam 1 gene in fission yeast.

\section{RESULTS}

\section{The 5' UTR mRNA of sam 1 mediates reporter gene expression on the addition of methionine}

The 5' UTR mRNA of Spe2 has recently been found to regulate translation upon spermidine binding consistent with a regulatory function in the polyamine biosynthetic pathway in S. pombe (Sun et al. 2020). We developed a reporter assay investigating the translational function of the 5' UTR mRNAs of key enzymes of the $S$. pombe SAM biosynthesis pathway in response to SAM (Fig. 1). In fission yeast, SAM levels are tightly controlled and SAM is produced by the coordinated action of several enzymes; adenosylmethionine synthetase (sam1), homocysteine methyltransferase (Met26), cysteine-S-conjugate $\beta$-lyase (cys). As SAM is unstable and impermeable under cell growth conditions, intracellular SAM levels can be controlled by exogenously supplementation of methionine that turns into SAM in S. pombe cell (Hilti et al. 2000); which is also true in bacteria (Winkler et al. 2003). The $h$ leu1-32 strain was used as a host strain for the reporter plasmid REP81X-lacz, which contains a thiamine-repressive nmt81 promoter (Pnmt81), cloning sites, and the $\beta$-galactosidase ( $\beta$-gal) reporter gene (Forsburg 1993). The $5^{\prime}$ UTR of sam1, Met26 or cys was mapped by 5'RACE (Supplemental Fig. S1), and the corresponding DNA sequences were each cloned between Pnmt81 and the $\beta$ gal reporter gene of the plasmid (Fig. 2A). The reporter plasmid was transformed into the $h$-leu1-32 strain, and $\beta$ gal activity measured for each construct in solution on titration of added methionine with or without thiamine. In the absence of thiamine (Pnmt81 promoter is active) when the $5^{\prime}$ UTR mRNA of sam 1 was transcribed, highly reproducible repression of $\beta$-gal expression was observed with methionine (Fig. 2B). As a critical control in the presence of 


\section{Zhang et al.}

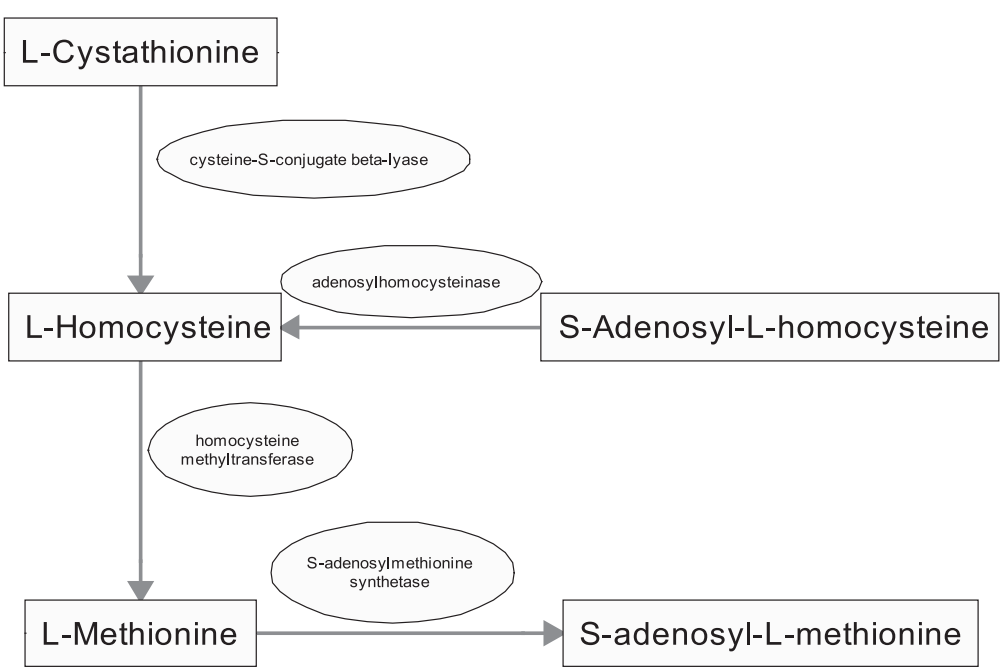

FIGURE 1. The SAM biosynthesis pathway in S. pombe.

of coding sequence, which also contains the primer sequence for reverse transcriptase detection of modified RNA, used in subsequent chemical probing experiments) and has an $\mathrm{AU}$ content of $66 \%$, both of which make it challenging for high-resolution biophysical measurements. The binding of SAM to the UTR of sam 1 in comparison with its related structural analogs (methionine, SAH, dc-SAH or MTA [Fig. 3A]) was measured by quenching of the fluorescence signal upon ligand binding in a Monolith NT.115 instrument (Entzian and Schubert 2016; Moon et al. 2018; Wang et al. 2019). RNA was prepared by in vitro transcription using T7 RNA polymerase and labeled with fluorescein. The

thiamine (promoter is repressed), when the UTR RNA was not made, only background levels of $\beta$-gal expression were observed in the absence or presence of methionine (Fig. 2B). As an additional control, cells transformed with the empty vector with no DNA sequence inserted, showed no $\beta$-gal expression on methionine titration with or without thiamine (Fig. 2B). Therefore, the observed repression is directly related to the production of the sam1 RNA transcript. For the construct containing the corresponding DNA sequence of the $5^{\prime}$ UTR of Met26 or cys, in the absence of thiamine, where the $5^{\prime}$ UTR RNA was transcribed by the Pnmt81 promoter, $\beta$-gal expression was unchanged in the absence or presence of methionine. In contrast to the $5^{\prime}$ UTR of sam 1, for the $5^{\prime}$ UTRs of Met26 or cys the $\beta$-gal expression is unresponsive to methionine. These results together suggest that the repression of $\beta$-gal expression is dependent on the transcribed $5^{\prime}$ UTR RNA of sam 1 and supplementation by methionine.

Regulatory RNAs can regulate gene expression at the level of transcription or translation (Breaker 2018). To test if the repression of the $\beta$-gal gene in the reporter assay occurs at the transcriptional level, mRNA abundance of $\beta$-gal reporter on titration of methionine was measured by realtime PCR. Titration of methionine shows very little change in $\beta$-gal mRNA abundance relative to the control (Tubulin) (Fig. 2C). Thus, repression of the $\beta$-gal gene in reporter assays probably occurs at the level of translation.

\section{SAM binds to the $5^{\prime}$ UTR RNA of sam 1 in vitro}

Because the 5' UTR mRNA of sam1 mediates reporter gene expression upon supplementation of methionine, we speculated that direct interactions between the $5^{\prime}$ UTR RNA of sam1 and SAM may be responsible for the $\beta$-gal repression in the reporter assay. The UTR mRNA of sam 1 is 235 nucleotides in length (185 nt UTR with $50 \mathrm{nt}$ change in fluorescent signal was consistent with SAM binding to the RNA with an affinity of $117 \mu \mathrm{M}$. (Fig. 3B). In each sample the full fluorescence signal was restored when the sample was denatured at $95^{\circ} \mathrm{C}$ in $10 \%$ pyridine (Fig. 3C). However, no binding for SAH (Fig. 3D) or the related structural analogs was detected under the same conditions (Supplemental Fig. S2). Therefore, the sam1 RNA binds SAM specifically. Methionine is converted into SAM in cells (Hilti et al. 2000). Supplementation of the cell medium with methionine (the SAM precursor) causes repression of $\beta$-gal expression, however methionine did not bind to the RNA by fluorescence quenching, rulingout the possibility that $\beta$-gal repression was caused by direct binding of methionine to the $5^{\prime}$ UTR RNA of sam 1 . The $\beta$-gal repression was dependent on the direct binding of SAM and 5' UTR RNA of sam1. Overall the binding data is consistent with and supports the results of the reporter assays.

\section{Secondary structure of sam1 UTR RNA}

Dimethyl sulphate (DMS) methylates unpaired adenine at N1 and cytosine at N3 nucleotide in structured RNA. Methylated $\mathrm{A}$ or $\mathrm{C}$ terminate reverse transcriptase in primer extension. DMS chemical probing was used to investigate the secondary structure of the $5^{\prime}$ UTR mRNA of sam1 (Tijerina et al. 2007; Jia et al. 2013) in the presence or absence of SAM by primer extension detected by capillary electrophoresis with fluorescence detection. The 235 nt $5^{\prime}$ UTR mRNA of sam 1 was modified by DMS, and a set of electropherograms was obtained with or without SAM (Fig. 4A,B) The results show fluorescent peaks that correspond to the positions of As and Cs that are reactive toward DMS, and indicate unpaired or perturbed regions in the structured RNA. Conversely, base-pairing protects the RNA against modification by DMS and is associated 
A

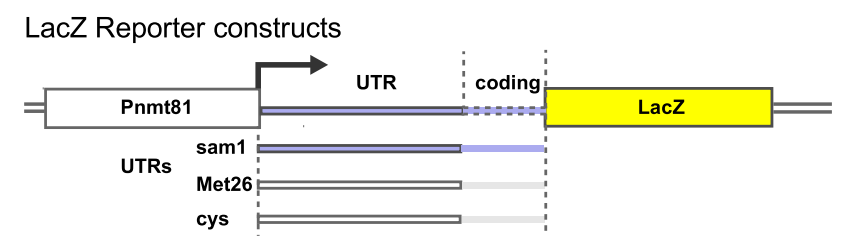

B
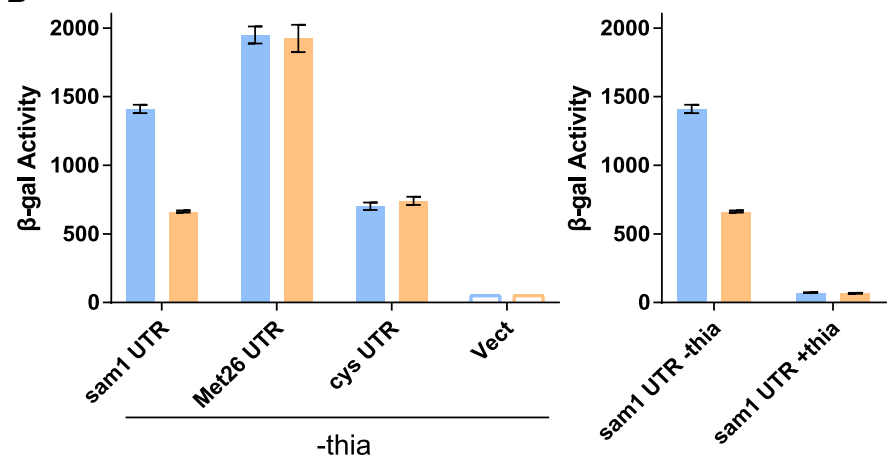

Real-time PCR

C

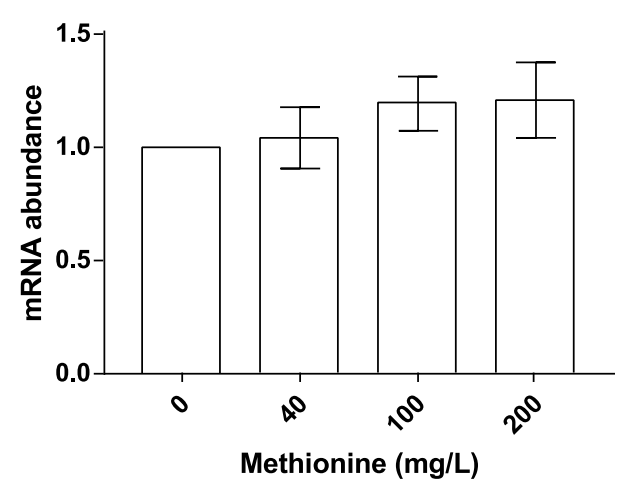

FIGURE 2. Methionine control of reporter gene expression through the $5^{\prime}$ UTR of sam1. (A) The Pnmt81-leaderRNAsam1/Met/cys-lacZ $\alpha$ constructs used in this study. (B) $\beta$-galactosidase expression in S. pombe cells transformed with the UTR constructs as indicated. Cells were grown in EMM media in methionine 0 or $200 \mathrm{mg} / \mathrm{L}$. Error bars are standard deviations of at least three independent experiments. (C) Real-time PCR analysis of mRNA abundance of the sam1 UTR RNA relative to the internal control tubulin.

with regions of low reactivity. The positions of DMS reactivities were used as constraints for RNA secondary structure prediction by computational RNA folding (Zuker 2003). Small differences in DMS reactivities were observed on addition of SAM, for example, the DMS sensitive positions 99A and 104A show reduced reactivities. However, these differences are not consistent with a major rearrangement of the secondary structure, and do not change the mfold folding constraints. Such alterations in reactivity may well be due to local changes in the tertiary structure of the RNA upon SAM binding. The chemical probing (DMS) data combined with computational folding (mfold) predicts a secondary structure for the $5^{\prime}$ UTR mRNA of sam 1 plus or minus SAM (Fig. 4C; Tijerina et al. 2007). The RNA adopts a compact secondary structure, divided into 2-domains, the first ( $5^{\prime}$ domain) contains two hairpin loops (L1, L2), and the second $3^{\prime}$ domain is composed of a 6 bp double-stranded region (Stem I) that encloses a series of single-stranded internal loops ( $L 4$, L6) and hairpin loops (Stem II; L3 and Stem III; L5) arranged about a helical junction (Figs. 4A,C, 6A).

\section{Osmium tetroxide $\left(\mathrm{OsO}_{4}\right)$ detects tertiary structural changes in the sam1 UTR RNA upon SAM binding}

The chemical probe $\mathrm{OsO}_{4} /$ pyridine modifies RNA at the 5-6 double bond of pyrimidines, mainly at unstacked uracil residues that are conformationally exposed on the surface of the folded RNA. Changes in the reactivity at unstacked uracils toward $\mathrm{OsO}_{4}$ /pyridine may serve as an indication of tertiary structure changes in the RNA in response to different conditions (Zhang et al. 2017). The $5^{\prime}$ UTR mRNA of sam 1 is enriched in AU nucleotides. We therefore probed the RNA with $\mathrm{OsO}_{4}$ /pyridine on titration of SAM. A set of electropherograms composed of a series of fluorescent peaks (Fig. 5A) was obtained by the $\mathrm{OsO}_{4}$-modified RNA. The fluorescence signals reflect the reactivity of $\mathrm{OsO}_{4}$ modification at each nucleotide. A number of fluorescent peaks were detected, as expected the majority of peaks corresponded to $\mathrm{OsO}_{4}$-modified uracils (Supplemental Fig. S3). SAM titration results in changes in $\mathrm{OsO}_{4}$ reactivity at specific nucleotides. The most striking change generated by SAM titration was at nucleotides 138G-142U within a predicted loop (L5). Without SAM, high fluorescent peaks were observed at nucleotides 138G-140U, and upon SAM titration, the $\mathrm{OsO}_{4}$ reactivity at 138G-140U became progressively reduced. The reduction in $\mathrm{OsO}_{4}$ reactivity as measured $140 \mathrm{U}$ was consistent with a $K_{D}$ of SAM for the RNA of $\sim 68 \mu \mathrm{M}$ (Fig. $5 B)$. This indicates that a conformational change occurred upon SAM binding such that the loop L5 nucleotides 138G-140U became less unstacked and less accessible to $\mathrm{OsO}_{4}$ modification. 
A

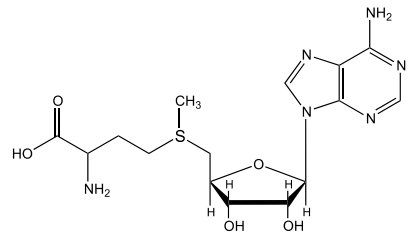

SAM

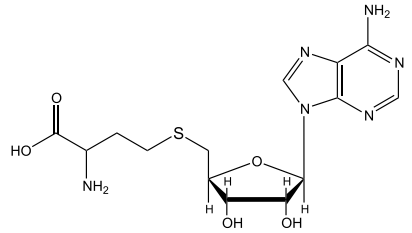

$\mathrm{SAH}$

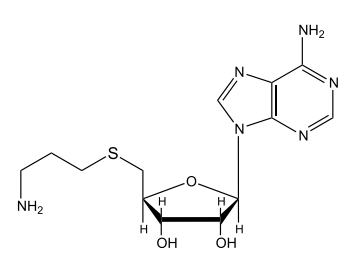

dc-SAH
B

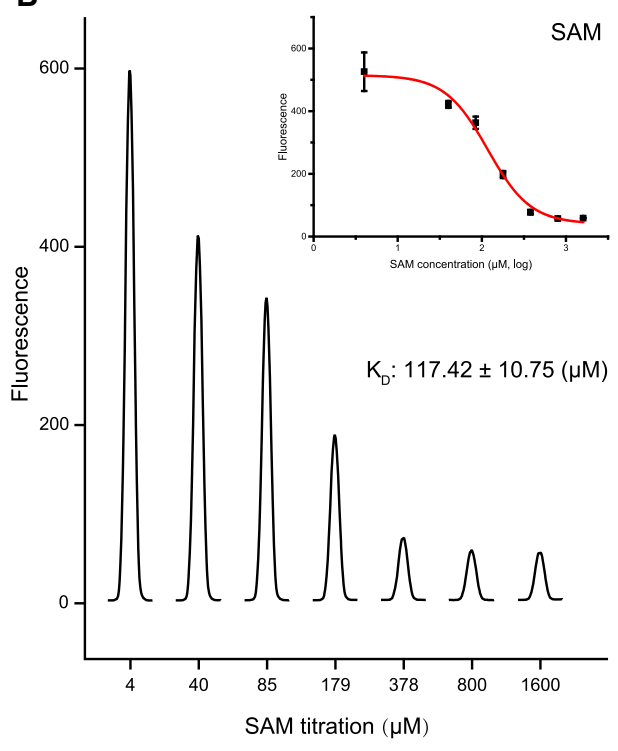

C

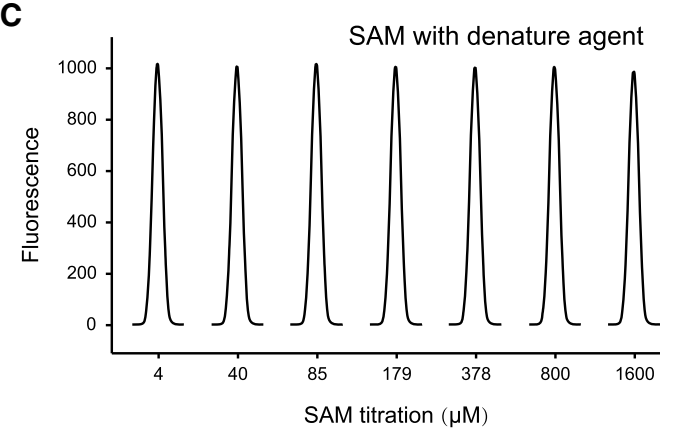

D

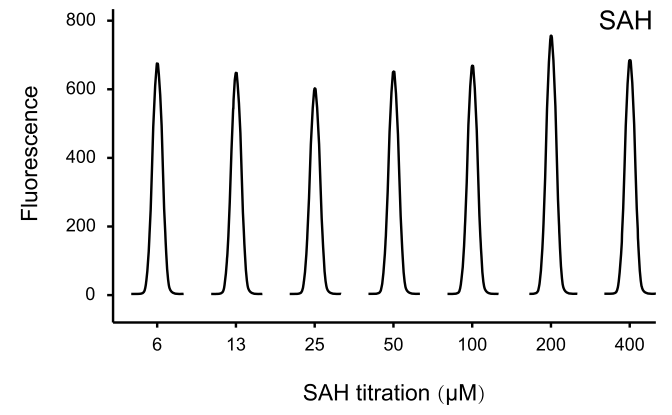

FIGURE 3. SAM binds to the sam1 UTR RNA. (A) Chemical structures of various compounds used to probe the binding characteristics of the sam 1 UTR RNA. (B) The change in fluorescence intensity on titration of SAM with the fluorescein-labeled sam1 UTR RNA, the SAM binding curve is shown in the inset. Error bars are the standard deviations of at least three independent experiments. (C) The fluorescence intensity of the fluorescein-labeled sam 1 UTR RNA-SAM complex samples from B under denaturing conditions. (D) SAH does not bind to the sam 1 UTR RNA; fluorescence intensity measurements on titration of SAH with the fluorescein-labeled RNA.

\section{Mechanism of sam1 UTR RNA regulation of SAM- dependent gene expression}

Reporter assay results suggest that the interaction between sam1 UTR RNA and SAM may play an important role in the regulation of translation. Structural changes in the RNA upon SAM binding were detected by $\mathrm{OsO}_{4}$ probing. Thus, the RNA may interact with the translation machinery to control basal levels of translation in the absence of SAM or regulate translation upon SAM binding through changes in the structure.
To dissect the functional components of the RNA structure, we made a series of mutations (Fig. 6A,B): three pairs of restorative and disruptive mutations on stem I (M9-10), II (M11-12), and III (M13-14), and several point mutations (M1-8). The effect of these RNA mutations on translation upon titration of SAM was determined by reporter assays and compared to the wild-type RNA (Fig. 6B-D). Based on the effect of the mutations on translation, they can be divided into three groups: mutations that have no effect on translation with or without SAM (M9 and M11), 
A<smiles>C[AsH2][AsH3]</smiles>

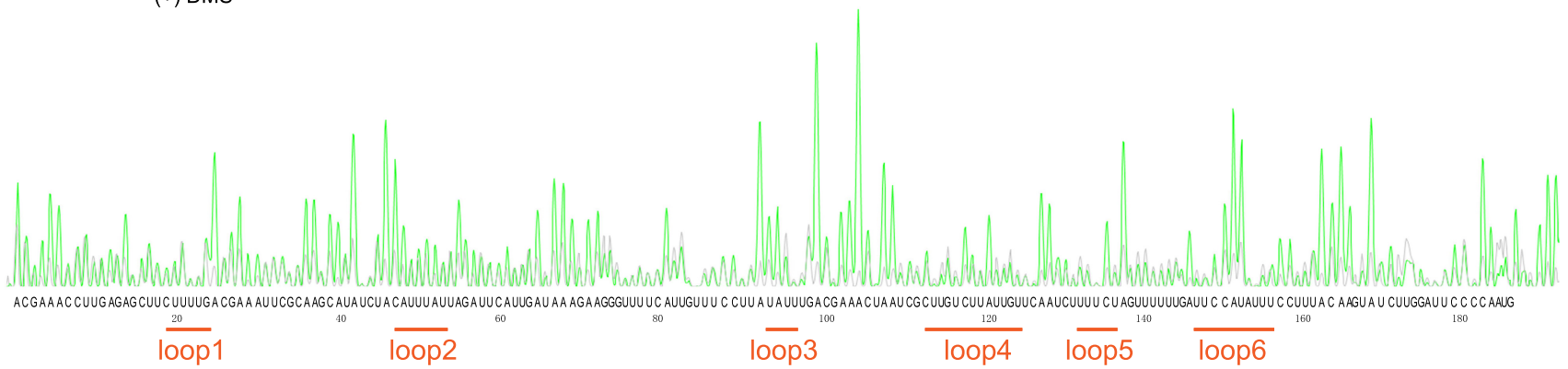

B (+) SAM with DMS

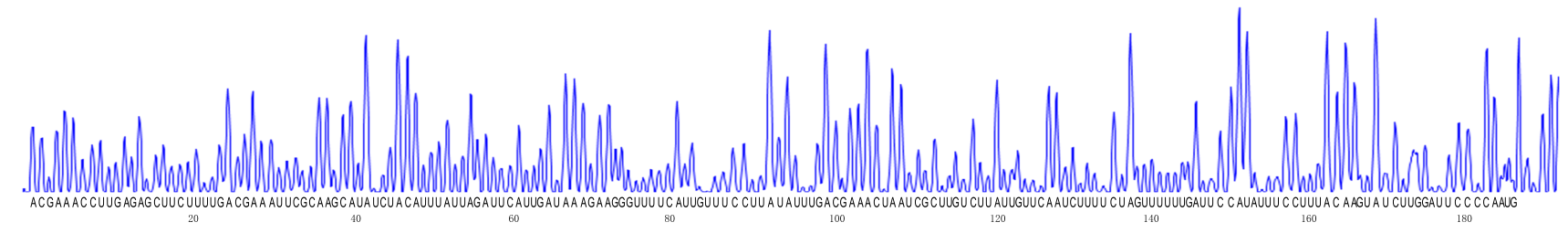

C

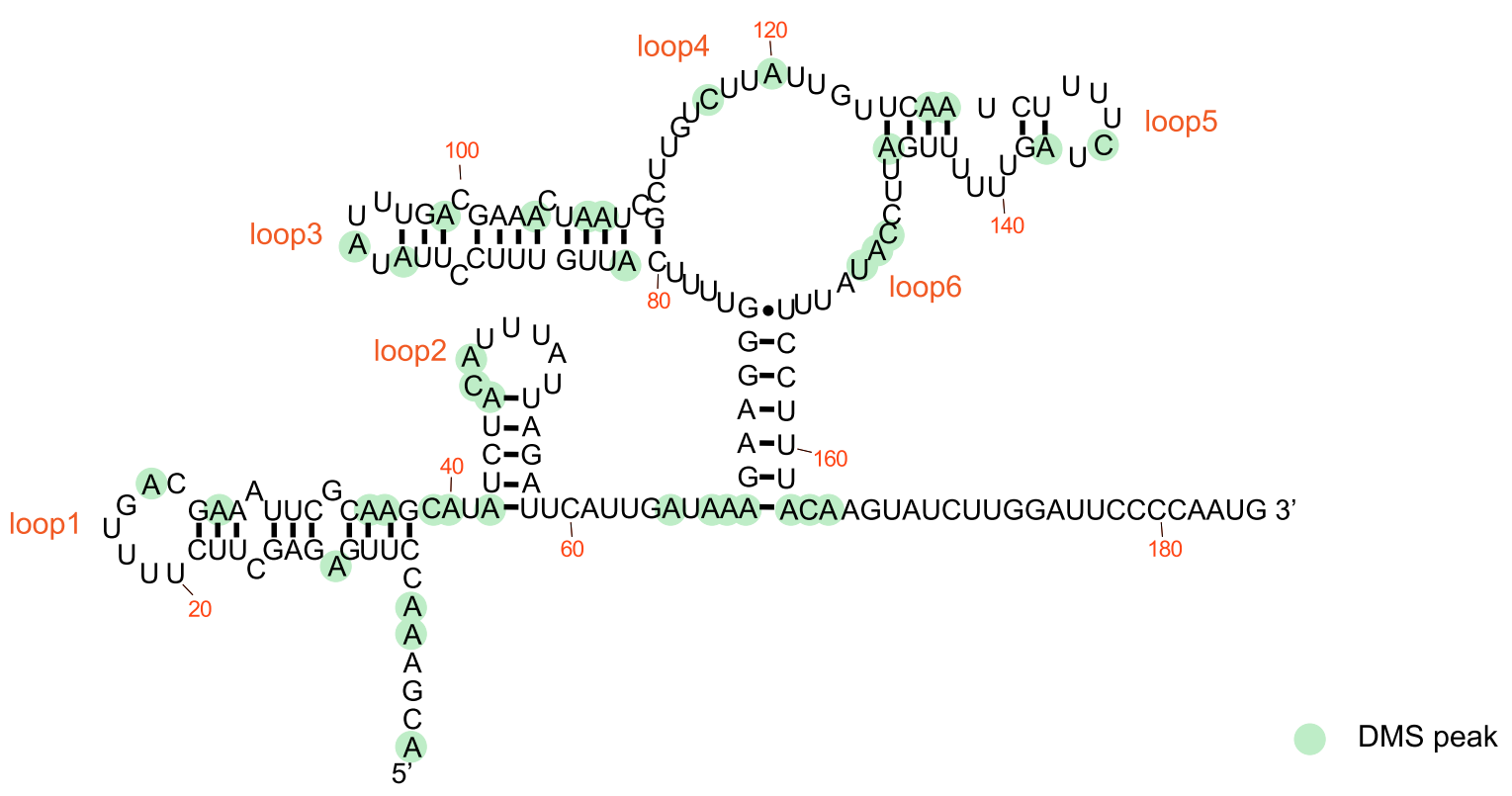

FIGURE 4. The secondary structure of the $5^{\prime}$ UTR of sam1 RNA. (A) DMS probing analysis of the sam 1 UTR RNA in the absence of SAM. (B) DMS probing analysis of the sam 1 UTR RNA in the presence of SAM. (C) Predicted secondary structure of the sam 1 UTR RNA by computational folding and structure probing analysis; DMS reactive nucleotides are labeled in green.

mutations that cause loss of response to SAM but retain basal levels of translation (M1-8 and M12) and mutations that completely abolish translation either with or without SAM (M10, M13, and M14). The restorative mutant M9 that retains base-pairing in stem I has a similar translational response to the wild-type RNA, both in terms of the basal level and also with SAM, in contrast, the disruptive mutation of stem I (M10) showed no translation with or without SAM indicating that formation of stem $I$ is essential for the basal level of translation. The disruptive mutant M12, at stem II retains basal levels of translation compared to the wild-type RNA, but loses the response to SAM. The restorative mutation of stem II, M11 had basal translation and regained some SAM response. The translational effects of M11-12 suggests that stem II plays a role in the response to SAM. Both disruptive and restorative mutations in stem III (M13-14) lead to the complete abolition of translation. Note that the mutations M13-14 neighbor or overlap the 138G-140U region where $\mathrm{OsO}_{4} /$ pyridine reactivity was suppressed on titration of SAM. These mutations (M13- 


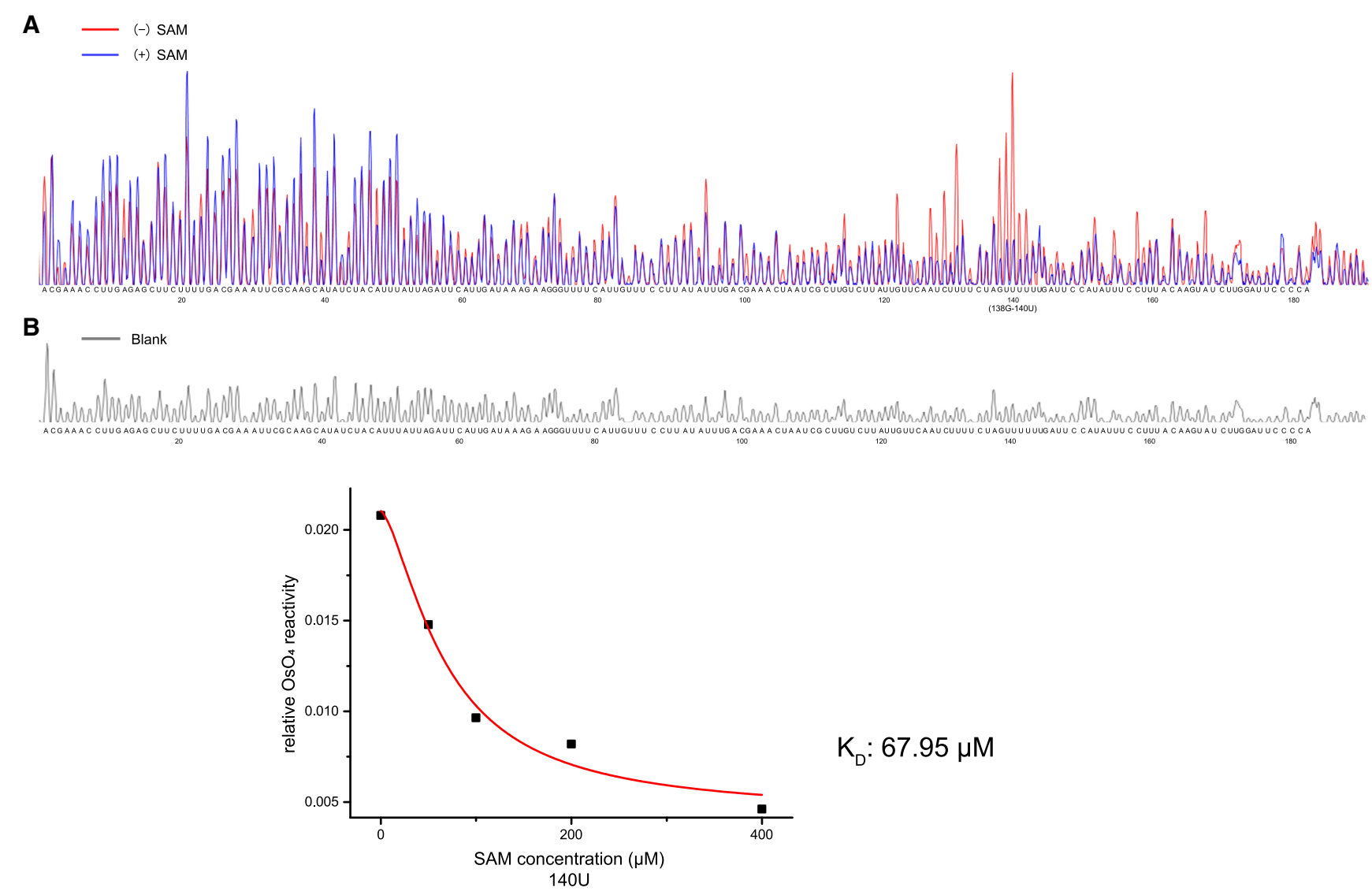

FIGURE 5. $\mathrm{OsO}_{4}$ probing of the tertiary structure of sam1 RNA on SAM binding. (A) Electropherogram of OsO ${ }_{4}$-modified RNA in the presence of $400 \mu \mathrm{M}$ SAM (blue trace), no SAM (red trace), or blank control (gray trace). (B) SAM binding measured through changes in $\mathrm{O} \mathrm{O}_{4}$ reactivity at the $140 \mathrm{U}$ position in the RNA, on titration with SAM (data taken from Supplemental Fig. S3).

14) suggest that stem III and the region adjoining 138G$140 \mathrm{U}$ are also important for basal levels of translation. The point mutations in stem III M2-M5 are unchanged on the addition of SAM although $\mathrm{M} 2$ and $\mathrm{M} 5$ have reduced levels of basal translation. A point mutation (M8, A120U) in the internal loop (L4) retains basal levels of translation, but is unresponsive on addition of SAM.

To further investigate whether specific tertiary structural changes upon SAM binding were responsible for the observed repression of translation, mutant RNAs were probed with $\mathrm{OsO}_{4}$ on titration of SAM and compared to the wildtype RNA. In the wild-type RNA, the reactivity of $\mathrm{OsO}_{4}$ toward 138G-140U became progressively weaker with titration of SAM, and similar changes in reactivity were observed in the restorative mutations of stem I (M9) and stem II (M11), in which wild-type patterns of repression are restored in the reporter assay (Figs. 6D, 7). However, $\mathrm{OsO}_{4}$ reactivity in loop $\mathrm{III}$ at positions $138 \mathrm{G}-140 \mathrm{U}$ in the inactive mutants M10 (in stem I), M12 (in stem II) or M13-14 do not titrate with added SAM (Fig. 7). There is therefore a good correlation between the tertiary structure of the RNA and the observed level of translation, suggesting that the tertiary structure transition of RNA upon SAM bind- ing may be responsible for the repression of translation. A comparison of $\mathrm{OsO}_{4}$ probing of the point mutations $\mathrm{M1}-4$ with the wild-type RNA is shown in Figure 6E (M2 A128U161) and Supplemental Figure S4 (M1-4 full length RNA). The accessibility of the $\mathrm{OsO}_{4}$ probe to some nucleotides in the mutants differs compared to that of the wildtype RNA (Fig. 6E; Supplemental Fig. S4), suggesting that even single point mutations may alter the tertiary structure such that it becomes unresponsive to SAM. Thus, a specific structure is required for translation and the change in RNA structure in the presence of SAM is essential for the repression of translation. Thus, the sam1 RNA may act as a biosensor such that the presence of SAM causes conformational changes that regulate translation.

\section{DISCUSSION}

Here we show that the UTR mRNA of the sam1 gene plays an important role in the regulation of translation through an RNA structure transition upon SAM binding. The following evidence supports this conclusion: (i) The regulation of reporter gene expression required both the presence of the UTR mRNA of the sam 1 gene and the SAM precursor 
A

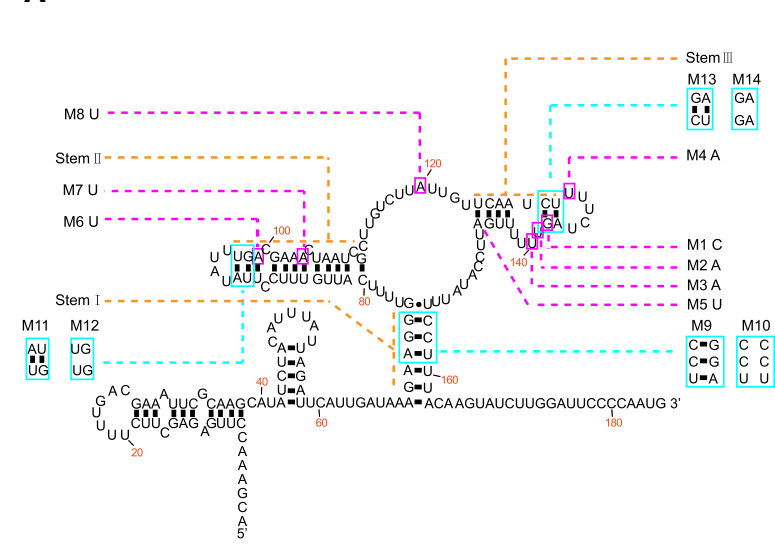

$\mathbf{C}$

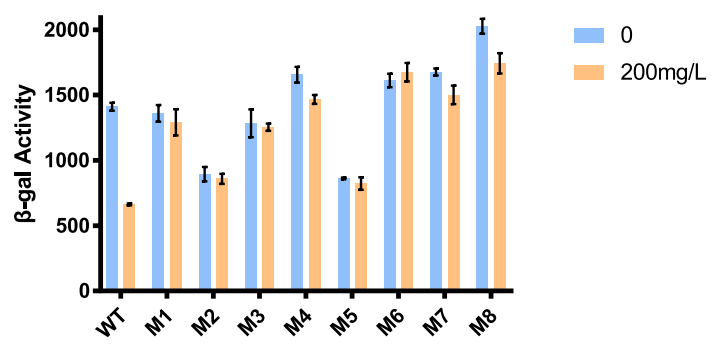

B

\begin{tabular}{|c|c|c|c|c|}
\hline Class & Mutant & Position & $\begin{array}{l}\text { Relative } \\
\text { Repression }\end{array}$ & $\begin{array}{c}\text { Tertiary } \\
\text { structure } \\
\text { change }\end{array}$ \\
\hline WT & WT & -- & 1 & -- \\
\hline \multirow{8}{*}{$\begin{array}{l}\text { point } \\
\text { mutation }\end{array}$} & M1 & G138C & 0.05 & Yes \\
\hline & M2 & U139A & 0.04 & Yes \\
\hline & M3 & U140A & 0.02 & Yes \\
\hline & M4 & U132A & 0.12 & Yes \\
\hline & M5 & $\mathrm{A} 146 \mathrm{U}$ & 0.05 & Yes \\
\hline & M6 & A99U & -0.04 & Yes \\
\hline & M7 & $\mathrm{A} 104 \mathrm{U}$ & 0.11 & Yes \\
\hline & M8 & A120U & 0.15 & Yes \\
\hline \multirow{3}{*}{$\begin{array}{c}\text { restorative } \\
\text { secondary } \\
\text { structure } \\
\text { mutation }\end{array}$} & M9 & A72U-G74C, C157G-U159A & 1.10 & No \\
\hline & M11 & U91A-A92U, U97A-G98C & 0.26 & No \\
\hline & M13 & C130G-U131A, A137U-G138C & -- & Yes \\
\hline \multirow{3}{*}{$\begin{array}{l}\text { disruptive } \\
\text { secondary } \\
\text { structure } \\
\text { mutation }\end{array}$} & M10 & A72U-G74C & - & Yes \\
\hline & M12 & U91A-A92U & 0.03 & Yes \\
\hline & M14 & C130G-U131A & -- & Yes \\
\hline
\end{tabular}

D

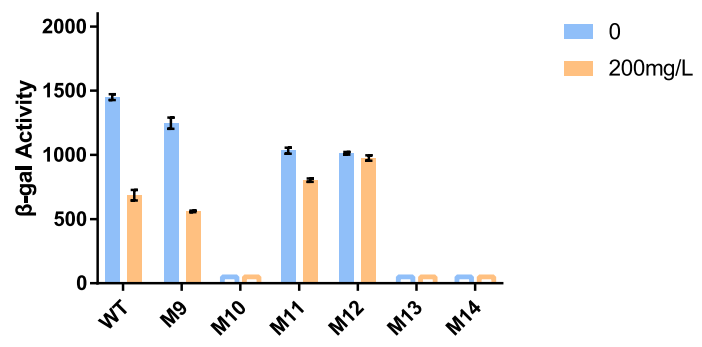

$\mathbf{E}$

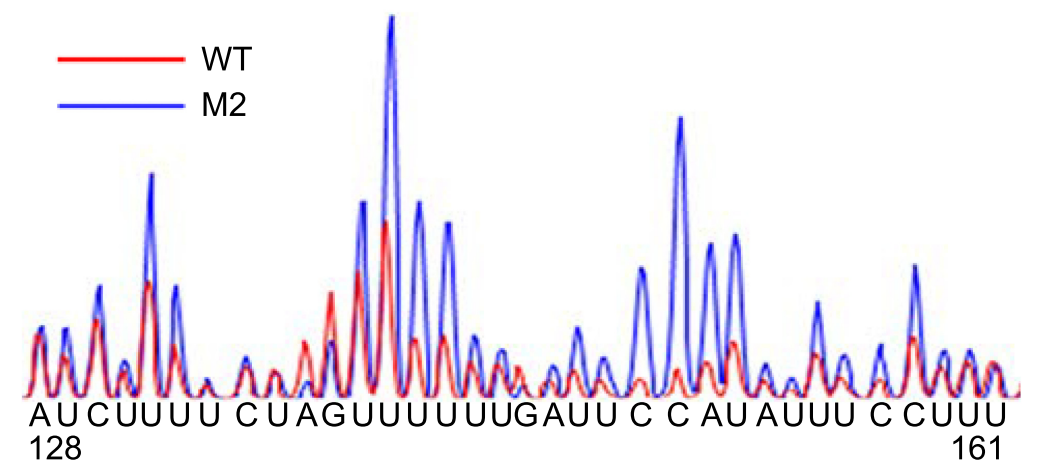

FIGURE 6. The functional and structural specificity of SAM-RNA binding. (A) The positions and identities of the mutations on the RNA. (B) The $\beta-$ gal activity of the $5^{\prime}$ UTR RNA mutations in the presence of $200 \mathrm{mg} / \mathrm{L}$ methionine. Mutant RNA repression is expressed as a proportion of wild-type RNA repression. The positions of the potential functional sites in the RNA are indicated. (C) $\beta$-galactosidase expression data of the wild-type UTR and M1-M8 point mutant RNAs in S. pombe cells. Cells were grown in EMM media in the absence of thiamine with or without $200 \mathrm{mg} / \mathrm{L}$ methionine. Error bars are standard deviations of at least three independent experiments. (D) $\beta$-galactosidase expression data of the wild-type UTR and M9-M14 mutant RNAs in S. pombe cells. Cells were grown in EMM media in the absence of thiamine with or without $200 \mathrm{mg} / \mathrm{L}$ methionine. Error bars are standard deviations of at least three independent experiments. (E) Electropherogram of $\mathrm{OsO}_{4}$ modification of the $5^{\prime}$ UTR of the sam1 RNA (nucleotides 128-161), comparing the reactivity of the mutation M2 (U139A) (the blue trace) with wild-type RNA (red trace).

methionine (Fig. 6C,D). (ii) Specific SAM binding to the UTR mRNA of the sam 1 gene was measured by fluorescence quenching which could distinguish between structural analogs of SAM that did not bind (Fig. 3; Supplemental Fig. S2). (iii) The RNA secondary structure was analyzed by DMS and $\mathrm{OsO}_{4}$ chemical probing to reveal that the sam1 UTR RNA undergoes a tertiary structure transition upon SAM binding (Figs. 4A, B, 5A). (iv) Mutational analysis identified important RNA structural elements that contribute to basal translation and translational regulation upon SAM binding. SAM-dependent repression of reporter gene translation was observed in the natural sam1 RNA. Mutations to the RNA in which SAM-dependent repression was retained underwent a 

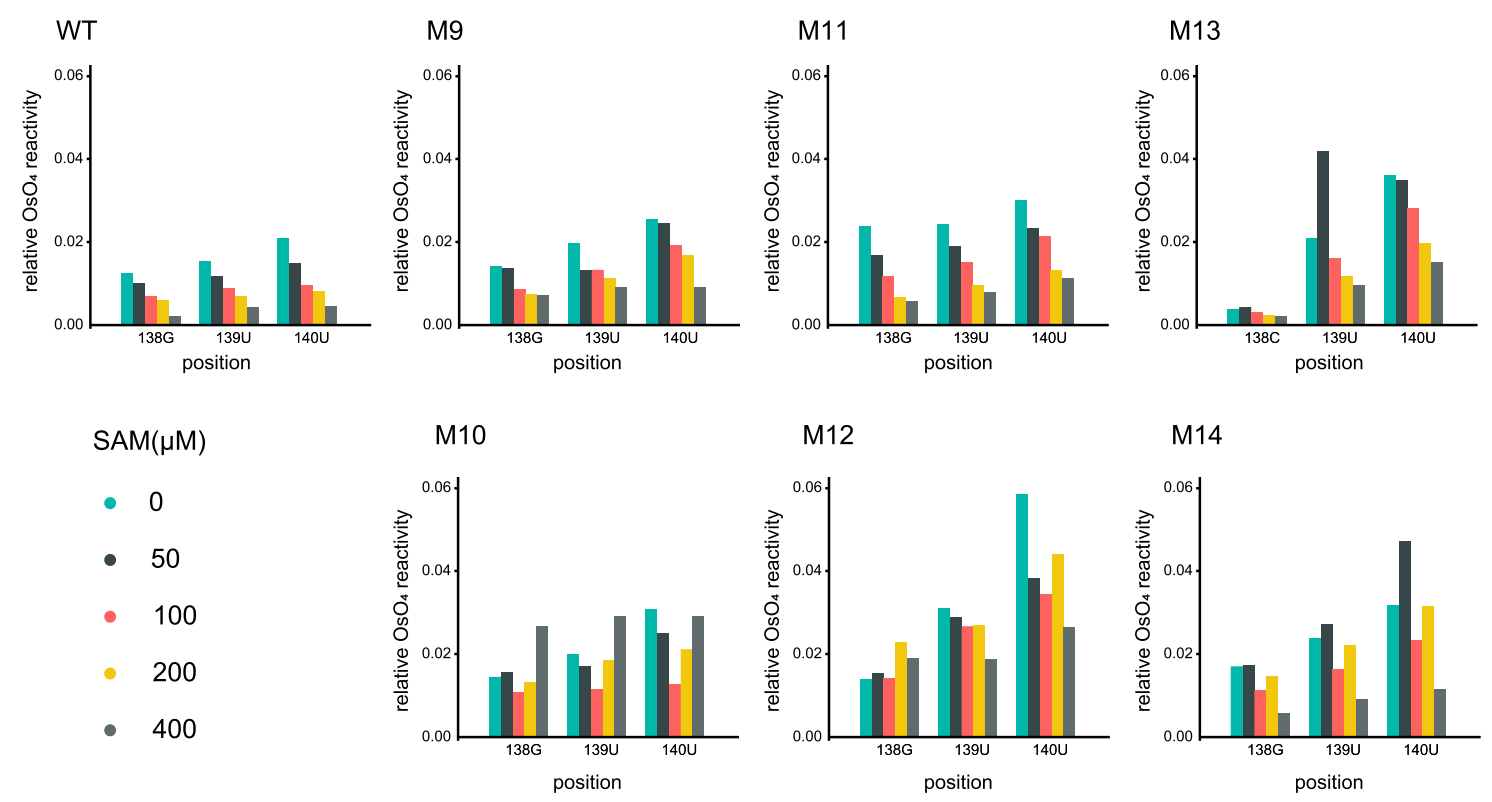

FIGURE 7. Relative $\mathrm{OsO}_{4}$ reactivities of the RNA nucleotides (138-140) of wild-type and M9-M14 mutant RNAs, on titration of SAM.

similar structural transition to the wild-type RNA, that could be detected by $\mathrm{OsO}_{4}$ probing. However, mutations to the RNA that do not respond to SAM in reporter assays, displayed an altered structural transition upon $\mathrm{OsO}_{4}$ probing. Thus, regulation of reporter gene translation in response to SAM is dependent on the tertiary structure transition in sam 1 UTR RNA upon SAM binding (Figs. 6D, 7).

As a translational regulatory mechanism, there are similarities between the function of the $5^{\prime}$ UTR mRNA of sam 1 in prokaryotes and eukaryotes. The bacterial $5^{\prime}$ UTR mRNA of the sam1 genes (SAM II-VI riboswitch RNAs) bind SAM to control translation of SAM synthetase and regulate SAM metabolism with negative feedback. Analogously, we have shown that the 5' UTR mRNA mediates translation of the sam 1 gene in fission yeast, and like its prokaryotic counterparts it is also repressed by SAM with similar fold-changes and affinities (Figs. 2B, 3B; Corbino et al. 2005; Fuchs et al. 2006; Weinberg et al. 2008; Poiata et al. 2009; Mirihana Arachchilage et al. 2018). However, mechanisms of translation regulation are significantly different between prokaryotes and eukaryotes. In bacteria, although the formation of the translation initiation complex is comparatively well understood, recognition and accessibility of SD (ribosome-binding sites) sequences are critical drivers for the initiation of translation. SAM riboswitch RNAs undergo secondary structure transitions upon SAM binding that can sequester or release the SD sequence to repress or activate translational initiation, independently of additional protein factors (Breaker 2012). In contrast, mechanisms of eukaryotic translational initiation are less well understood. Eukaryotic translation initiation involves the coordinated assembly of ribosomal subunits, mRNA and at least nine eukaryotic initiation factors (elFs) to form initiation complexes. The initiation of translation may utilize either cap-dependent scanning mechanisms or cap-independent internal ribosome entry sites (IRESs). In addition, Kozak sequences on mRNA are not well conserved. The complexity and diversity of eukaryotic translation initiation poses enormous challenges for the understanding of its regulation. Here, although the mechanisms of translation initiation in S. pombe are relatively unexplored, we have shown that translational control of the sam 1 gene in $S$. pombe was associated with a structural transition in the sam1 5' UTR mRNA, caused by SAM binding (Figs. 6D, 7). Certain mutations in the sam $15^{\prime}$ UTR, notably M10 in stem I or M13-14 in stem III completely abolished translation and we speculate that the sites of these mutations may interact directly with the translation apparatus. The mutation M10 that disrupts stem I may also render the RNA susceptible to degradation through the generation of $5^{\prime}$ and $3^{\prime}$ single-stranded regions in the RNA, emphasizing the importance of stem I in stabilizing the secondary structure for translation of the RNA (Houseley and Tollervey 2009).

Recently uORFs have been reported to have regulatory roles in eukaryotic translation initiation (Miller-Fleming et al. 2015). A genome-wide study of ribosomal pulldown profiles identified all of the uORFs in S. pombe (Duncan and Mata 2014); we note that no uORFs were associated with the $5^{\prime}$ UTR mRNA of the sam 1 gene.

Tertiary folding of the $5^{\prime}$ untranslated regions of eukaryotic mRNAs may regulate the initiation of translation through interactions with the translational apparatus. A growing body of independent studies are continuing to reveal a variety of factors and conditions that contribute to the control of translation initiation in higher organisms (Leppek et al. 2017). The accumulation of additional 
case-studies will enhance our understanding of these mechanisms. Here we have focused on biochemical evidence for a regulatory function of the 5' UTR mRNA of sam 1 and demonstrated a role for the RNA in the translation of the sam 1 gene. Identification of this unique eukaryotic SAM binding $5^{\prime}$ UTR mRNA that is involved in a fundamental metabolic process in fission yeast suggests the possibility of a more widespread role for ligand-sensing regulatory RNAs in eukaryotic gene expression.

\section{MATERIALS AND METHODS}

\section{Determination of the sam 1 UTR by $5^{\prime}$ RACE}

The transcription start site was identified using SMART RACE CDNA Amplification kit (Clontech), following the manufacturer's instructions.

\section{Construction of the reporter plasmid and mutagenesis}

The plasmid Rep81x-lacZ (Forsburg 1993) (a gift from the Forsburg laboratory) was used as a vector to clone the reporter plasmids in this study. The DNA sequences corresponding to the $5^{\prime}$ UTRs of sam1, homocysteine methyltransferase (Met26), and cysteine-S-conjugate $\beta$-lyase (Cys), were each amplified and cloned into the vector. Mutagenesis was conducted using the Site-Directed Mutagenesis kit (Clontech), following the manufacturer's instructions.

\section{The reporter assay in fission yeast}

The h-leu1-32 strain (a gift from the Jürg Bähler) cells that transformed with the reporter plasmid were cultured in EMM medium for $1 \mathrm{~d}$, and cells were diluted to an optical density (OD) 0.01 in EMM. Methionine was added to a final concentration of 0,200 $\mathrm{mg} / \mathrm{L}$, and cells grown for a further $24 \mathrm{~h}$. For the control sample, $60 \mu \mathrm{M}$ of thiamine was added in parallel to the medium, and $\beta$ gal activity were measured. Cells $\left(\sim 10^{6}\right)$ were harvested and resuspended in $1 \mathrm{~mL}$ of $Z$ buffer $\left(60 \mathrm{mM} \mathrm{Na}_{2} \mathrm{HPO}_{4}, 40 \mathrm{mM}\right.$ $\mathrm{NaH}_{2} \mathrm{PO}_{4}, 10 \mathrm{mM} \mathrm{KCl}, 1 \mathrm{mM} \mathrm{MgSO}$, 50 mM $\beta$-mercaptoethanol, $\mathrm{pH}$ 7.0). Cells were diluted thrice with $\mathrm{Z}$ buffer, and $600 \mu \mathrm{L}$ of cell suspension was mixed with $70 \mu \mathrm{L}$ of chloroform and $60 \mu \mathrm{L}$ of $0.1 \%$ SDS, followed by mixing for $10 \mathrm{sec}$, and incubated at $30^{\circ} \mathrm{C}$ for 15 min, after adding $120 \mu \mathrm{L}$ of $4 \mathrm{mg} / \mathrm{mL}$ o-nitrophenyl $\beta$-D-galactopyranoside (ONPG), and further incubated for $15-20 \mathrm{~min}\left(30^{\circ} \mathrm{C}\right)$. The reaction was quenched by the addition of $400 \mu \mathrm{L}$ of $1 \mathrm{M}$ sodium carbonate. The $\mathrm{OD}_{420}$ and $\mathrm{OD}_{600}$ were measured, and Miller units were calculated from the formula: $U=1000 \times \mathrm{OD}_{420} /[($ Time $) \times$ $(\mathrm{Vol}) \times \mathrm{OD}_{600}$ ] (Zhang and Bremer 1995).

\section{DMS probing}

DMS probing was performed as previously described (Tijerina et al. 2007; Jia et al. 2013). Briefly, a series of concentrations of SAM were incubated with 20 pmol of RNA in buffer $(50 \mathrm{mM}$ Tris- $\mathrm{KOH}$ [pH 8.0], $\mathrm{KCl} 100 \mathrm{mM}, 1 \mathrm{mM} \mathrm{MgCl} 2$ ), and RNA was probed by $0.5 \% \mathrm{DMS}$ (Sigma) at $25^{\circ} \mathrm{C}$ for $5 \mathrm{~min}$. DMSO instead of DMS was added as control sample. The reaction was stopped by the addition of $475 \mu \mathrm{L}$ stop solution (30\% [v/v] $\beta$-mercaptoethanol, $0.3 \mathrm{M}$ sodium acetate) and $1 \mathrm{~mL}$ ethanol and recovered by ethanol precipitation. Positions of modification were determined by reverse transcription and sequencing with a $5^{\prime}$ FAM-labeled primer.

\section{Real-time PCR}

Messenger RNA abundance of lacZ ( $\beta$-gal reporter) from the reporter plasmid was detected by real-time PCR with increasing amounts of SAM, using tubulin as a reference, as previously described (Jia et al. 2013).

\section{Osmium probing}

Osmium probing was performed as previously described (Zhang et al. 2017). Briefly, a series of concentrations of SAM were incubated with $\sim 20$ pmol of RNA in buffer ( $50 \mathrm{mM}$ Tris-KOH [pH 8.0], $\mathrm{KCl} 100 \mathrm{mM}, 1 \mathrm{mM} \mathrm{MgCl} 2$ ), and RNA was probed by $1 \mathrm{mM}$ of $\mathrm{OsO}_{4} /$ pyridine at $25^{\circ} \mathrm{C}$ for $35 \mathrm{~min}$. The reaction was stopped by ethanol precipitation, and the probing position was measured by reverse transcription and sequencing with a $5^{\prime}$ FAM-labeled primer. The control sample was included without $\mathrm{OsO}_{4} /$ pyridine.

\section{Fluorescence quenching}

The sam1 UTR RNA was prepared by in vitro transcription using T7 RNA polymerase. Purified RNA was labeled with fluorescein5-thiosemicarbazide as previously described (Wu et al. 1996). The FITC RNA and SAM or other analogs were both prepared in $50 \mathrm{mM}$ Tris- $\mathrm{NaOH}$ (pH 8.0), $100 \mathrm{mM} \mathrm{NaCl}$, and $1 \mathrm{mM} \mathrm{MgCl}$. The RNA was annealed by heating to $95^{\circ} \mathrm{C}$ for 2 min and then cooled to room temperature. SAM or other analogs were added and the samples incubated for $1 \mathrm{~h}$. Fluorescence intensities were detected in the capillary scan using the Monolith NT.115 system (NanoTemper Technologies). When fluorescence changes were observed, samples were denatured to validate ligand-dependent fluorescence changes. To each sample, 10\% (volume) pyridine was added. Samples were mixed and incubated for 2 min at $95^{\circ} \mathrm{C}$ to denature the samples and the fluorescence intensity measured.

\section{Computational RNA folding}

RNA secondary structures were predicted using the computational folding software mfold (mfold web server running version 3.6, http://unafold.rna.albany.edu/?q=mfold/RNA-Folding-Form) (Zuker 2003), incorporating the DMS chemical probing data for each nucleotide to constrain regions of double-stranded and single-stranded RNA. In Watson-Crick base-paired RNA, A or C nucleotides were unreactive toward methylation by DMS (Tijerina et al. 2007). In contrast, in unpaired RNA, the N1 position of adenosine and the N3 position of cytidine are sensitive toward modification by DMS, and methylation at these positions also blocks reverse transcription. Single-stranded nucleotides or perturbed regions in the RNA are therefore detected as high fluorescent 
signals (relative to the controls) in the electropherograms due to abortive reverse transcription; in contrast, base-paired regions of the RNA are comparatively unreactive and do not impede reverse transcriptase.

\section{SUPPLEMENTAL MATERIAL}

Supplemental material is available for this article.

\section{ACKNOWLEDGMENTS}

We thank Susan Forsberg for the gift of the plasmid Rep81x-lacZ, Jürg Bähler for the gift of the strain h-leu1-32, Gu Zhongkai for assistance with capillary sequencing, David Lilley (University of Dundee), and members of the Murchie laboratory for discussion. This work was supported by Natural Science Foundation grants 31370107 to D.C.; 31470777 to W.S.; 2016YFA0500604, 31420103907,31770873 , and 31330022 to A.M.

Received August 22, 2019; accepted October 14, 2019.

\section{REFERENCES}

Ben-Asouli Y, Banai Y, Pel-Or Y, Shir A, Kaempfer R. 2002. Human interferon- $\gamma$ mRNA autoregulates its translation through a pseudoknot that activates the interferon-inducible protein kinase PKR. Cell 108: 221-232. doi:10.1016/S0092-8674(02)00616-5

Bocobza S, Adato A, Mandel T, Shapira M, Nudler E, Aharoni A. 2007. Riboswitch-dependent gene regulation and its evolution in the plant kingdom. Genes Dev 21: 2874-2879. doi:10.1101/gad .443907

Breaker RR. 2012. Riboswitches and the RNA World. Cold Spring Harb Perspect Biol 4: a003566. doi:10.1101/cshperspect.a003566

Breaker RR. 2018. Riboswitches and translation control. Cold Spring Harb Perspect Biol 10: a032797. doi:10.1101/cshper spect.a032797

Cantoni GL. 1975. Biological methylation: selected aspects. Annu Rev Biochem 44: 435-451. doi:10.1146/annurev.bi.44.070175 .002251

Carrieri C, Cimatti L, Biagioli M, Beugnet A, Zucchelli S, Fedele S, Pesce E, Ferrer I, Collavin L, Santoro C, et al. 2012. Long noncoding antisense RNA controls Uchl1 translation through an embedded SINEB2 repeat. Nature 491: 454-457. doi:10.1038/ nature 11508

Castets M, Schaeffer C, Bechara E, SchenckA, Khandjian EW, Luche S, Moine H, Rabilloud T, Mandel JL, Bardoni B. 2005. FMRP interferes with the Rac1 pathway and controls actin cytoskeleton dynamics in murine fibroblasts. Hum Mol Genet 14: 835-844. doi:10.1093/hmg/ddi077

Cheah MT, Wachter A, Sudarsan N, Breaker RR. 2007. Control of alternative RNA splicing and gene expression by eukaryotic riboswitches. Nature 447: 497-500. doi:10.1038/nature05769

Corbino KA, Barrick JE, Lim J, Welz R, Tucker BJ, Puskarz I, Mandal M, Rudnick ND, Breaker RR. 2005. Evidence for a second class of Sadenosylmethionine riboswitches and other regulatory RNA motifs in $\alpha$-proteobacteria. Genome Biol 6: R70. doi:10.1186/gb2005-6-8-r70

Croft MT, Moulin M, Webb ME, Smith AG. 2007. Thiamine biosynthesis in algae is regulated by riboswitches. Proc Natl Acad Sci 104: 20770-20775. doi:10.1073/pnas.0705786105

Ding Y, Tang Y, Kwok CK, Zhang Y, Bevilacqua PC, Assmann SM. 2014. In vivo genome-wide profiling of RNA secondary structure reveals novel regulatory features. Nature 505: 696-700. doi:10 $.1038 /$ nature 12756

Duncan CDS, Mata J. 2014. The translational landscape of fissionyeast meiosis and sporulation. Nat Struct Mol Biol 21: 641-647. doi:10.1038/nsmb.2843

Entzian C, Schubert T. 2016. Studying small molecule-aptamer interactions using MicroScale Thermophoresis (MST). Methods 97: 2734. doi:10.1016/j.ymeth.2015.08.023

Forsburg SL. 1993. Comparison of Schizosaccharomyces pombe expression systems. Nucleic Acids Res 21: 2955-2956. doi:10 $.1093 /$ nar/21.12.2955

Fuchs RT, Grundy FJ, Henkin TM. 2006. The SMK box is a new SAMbinding RNA for translational regulation of SAM synthetase. Nat Struct Mol Biol 13: 226-233. doi:10.1038/nsmb1059

Gilbert SD, Rambo RP, Van Tyne D, Batey RT. 2008. Structure of the SAM-II riboswitch bound to S-adenosylmethionine. Nat Struct Mol Biol 15: 177-182. doi:10.1038/nsmb.1371

Gray NK, Hentze MW. 1994. Iron regulatory protein prevents binding of the $43 S$ translation pre-initiation complex to ferritin and eALAS mRNAs. EMBO J 13: 3882-3891. doi:10.1002/j.1460-2075.1994 .tb06699.x

Grundy FJ, Henkin TM. 2004. Kinetic analysis of tRNA-directed transcription antitermination of the Bacillus subtilis glyOS gene in vitro. J Bacteriol 186: 5392-5399. doi:10.1128/JB.186.16.53925399.2004

Hentze MW, Caughman SW, Rouault TA, Barriocanal JG, Dancis A, Harford JB, Klausner RD. 1987. Identification of the iron-responsive element for the translational regulation of human ferritin mRNA. Science 238: 1570-1573. doi:10.1126/science.3685996

Hilti N, Gräub R, Jörg M, Arnold P, Schweingruber AM, Schweingruber ME. 2000. Gene sam1 encoding adenosylmethionine synthetase: effects of its expression in the fission yeast Schizosaccharomyces pombe. Yeast 16: 1-10. doi:10.1002/(SICl) 1097-0061(20000115)16:1<1::AID-YEA501>3.0.CO;2-K

Houseley J, Tollervey D. 2009. The many pathways of RNA degradation. Cell 136: 763-776. doi:10.1016/j.cell.2009.01.019

Jackson RJ, Hellen CU, Pestova TV. 2010. The mechanism of eukaryotic translation initiation and principles of its regulation. Nat Rev Mol Cell Biol 11: 113-127. doi:10.1038/nrm2838

Jia X, Zhang J, Sun W, He W, Jiang H, Chen D, Murchie Al. 2013. Riboswitch regulation of aminoglycoside resistance acetyl and adenyl transferases. Cell 153: 1419-1420. doi:10.1016/j.cell.2013 .05 .050

Kertesz M, Wan Y, Mazor E, Rinn JL, Nutter RC, Chang HY, Segal E. 2010. Genome-wide measurement of RNA secondary structure in yeast. Nature 467: 103-107. doi:10.1038/nature09322

Kortmann J, Narberhaus F. 2012. Bacterial RNA thermometers: molecular zippers and switches. Nat Rev Microbiol 10: 255-265. doi:10.1038/nrmicro2730

Kortmann J, Sczodrok S, Rinnenthal J, Schwalbe H, Narberhaus F. 2011. Translation on demand by a simple RNA-based thermosensor. Nucleic Acids Res 39: 2855-2868. doi:10.1093/nar/gkq1252

Krajewski SS, Joswig M, Nagel M, Narberhaus F. 2014. A tricistronic heat shock operon is important for stress tolerance of Pseudomonas putida and conserved in many environmental bacteria. Environ Microbiol 16: 1835-1853. doi:10.1111/1462-2920 .12432

Kubodera T, Watanabe M, Yoshiuchi K, Yamashita N, Nishimura A, Nakai S, Gomi K, Hanamoto H. 2003. Thiamine-regulated gene expression of Aspergillus oryzae thiA requires splicing of the intron containing a riboswitch-like domain in the $5^{\prime}$-UTR. FEBS Lett 555: 516-520. doi:10.1016/S0014-5793(03)01335-8

Leppek K, Das R, Barna M. 2017. Functional 5' UTR mRNA structures in eukaryotic translation regulation and how to find them. Nat Rev Mol Cell Biol 19: 158-174. doi:10.1038/nrm.2017.103 
Loenen WA. 2006. S-adenosylmethionine: jack of all trades and master of everything? Biochem Soc Trans 34: 330-333. doi:10.1042/ BST0340330

Miller-Fleming L, Olin-Sandoval V, Campbell K, Ralser M. 2015. Remaining mysteries of molecular biology: the role of polyamines in the cell. J Mol Biol 427: 3389-3406. doi:10.1016/j.jmb.2015.06 .020

Mirihana Arachchilage G, Sherlock ME, Weinberg Z, Breaker RR. 2018. SAM-VI RNAs selectively bind S-adenosylmethionine and exhibit similarities to SAM-III riboswitches. RNA Biol 15: 371378. doi:10.1080/15476286.2017.1399232

Moon MH, Hilimire TA, Sanders AM, Schneekloth JS Jr. 2018. Measuring RNA-ligand interactions with microscale thermophoresis. Biochemistry 57: 4638-4643. doi:10.1021/acs.biochem .7b01141

Muckenthaler M, Gray NK, Hentze MW. 1998. IRP-1 binding to ferritin mRNA prevents the recruitment of the small ribosomal subunit by the cap-binding complex elF4F. Mol Cell 2: 383-388. doi:10 .1016/S1097-2765(00)80282-8

Muckenthaler MU, Rivella S, Hentze MW, Galy B. 2017. A red carpet for iron metabolism. Cell 168: 344-361. doi:10.1016/j.cell.2016 .12 .034

Mustoe AM, Busan S, Rice GM, Hajdin CE, Peterson BK, Ruda VM, Kubica N, Nutiu R, Baryza JL, Weeks KM. 2018. Pervasive regulatory functions of mRNA structure revealed by high-resolution SHAPE probing. Cell 173: 181-195.e18. doi:10.1016/j.cell.2018 .02 .034

Poiata E, Meyer MM, Ames TD, Breaker RR. 2009. A variant riboswitch aptamer class for $S$-adenosylmethionine common in marine bacteria. RNA 15: 2046-2056. doi:10.1261/rna.1824209

Rouskin S, Zubradt M, Washietl S, Kellis M, Weissman JS. 2014. Genome-wide probing of RNA structure reveals active unfolding of mRNA structures in vivo. Nature 505: 701-705. doi:10.1038/ nature12894

Schaeffer C, Bardoni B, Mandel JL, Ehresmann B, Ehresmann C, Moine H. 2001. The fragile $X$ mental retardation protein binds specifically to its mRNA via a purine quartet motif. EMBO J 20: 48034813. doi:10.1093/emboj/20.17.4803

Schubert HL, Blumenthal RM, Cheng X. 2003. Many paths to methyltransfer: a chronicle of convergence. Trends Biochem Sci 28: 329335. doi:10.1016/S0968-0004(03)00090-2

Serganov A, Nudler E. 2013. A decade of riboswitches. Cell 152: 1724. doi:10.1016/j.cell.2012.12.024

Sokabe M, Fraser CS. 2019. Toward a kinetic understanding of eukaryotic translation. Cold Spring Harb Perspect Biol 11: a032706. doi:10.1101/cshperspect.a032706

Stroynowski I, van Cleemput M, Yanofsky C. 1982. Superattenuation in the tryptophan operon of Serratia marcescens. Nature 298: 38-41. doi:10.1038/298038a0

Sudarsan N, Barrick JE, Breaker RR. 2003. Metabolite-binding RNA domains are present in the genes of eukaryotes. RNA 9: 644647. doi:10.1261/rna.5090103
Sun W, Zhang X, Chen D, Murchie AlH. 2020. Interactions between the 5' UTR mRNA of the spe2 gene and spermidine regulate translation in S. pombe. RNA 26: 137-149 (this issue). doi:10.1261/rna.072975.119

Tapsin S, Sun M, Shen Y, Zhang H, Lim XN, Susanto TT, Yang SL, Zeng GS, Lee J, Lezhava A. 2018. Genome-wide identification of natural RNA aptamers in prokaryotes and eukaryotes. Nat Commun 9: 1289. doi:10.1038/s41467-018-03675-1

Tijerina P, Mohr S, Russell R. 2007. DMS footprinting of structured RNAs and RNA-protein complexes. Nat Protoc 2: 2608-2623. doi:10.1038/nprot.2007.380

Vitreschak AG, Rodionov DA, Mironov AA, Gelfand MS. 2004. Riboswitches: the oldest mechanism for the regulation of gene expression? Trends Genet 20: 44-50. doi:10.1016/j.tig.2003.11.008

Wachter A, Tunc-Ozdemir M, Grove BC, Green PJ, Shintani DK, Breaker RR. 2007. Riboswitch control of gene expression in plants by splicing and alternative $3^{\prime}$ end processing of mRNAs. Plant Cell 19: 3437-3450. doi:10.1105/tpc.107.053645

Wang S, He W, Sun W, Zhang J, Chang Y, Chen D, Murchie AlH. 2019. Integron-derived aminoglycoside-sensing riboswitches control aminoglycoside acetyltransferase resistance gene expression. Antimicrob Agents Chemother 63: e00236-19. doi:10.1128/AAC .00236-19

Weinberg Z, Regulski EE, Hammond MC, Barrick JE, Yao Z, Ruzzo WL, Breaker RR. 2008. The aptamer core of SAM-IV riboswitches mimics the ligand-binding site of SAM-I riboswitches. RNA 14: 822828. doi:10.1261/rna.988608

Wickiser JK, Winkler WC, Breaker RR, Crothers DM. 2005. The speed of RNA transcription and metabolite binding kinetics operate an FMN riboswitch. Mol Cell 18: 49-60. doi:10.1016/j.molcel.2005.02.032

Winkler WC, Nahvi A, Sudarsan N, Barrick JE, Breaker RR. 2003. An mRNA structure that controls gene expression by binding $S$ adenosylmethionine. Nat Struct Mol Biol 10: 701-707. doi:10 .1038/nsb967

Wu TP, Ruan KC, Liu WY. 1996. A fluorescence-labeling method for sequencing small RNA on polyacrylamide gel. Nucleic Acids Res 24: 3472-3473. doi:10.1093/nar/24.17.3472

Xue S, Tian S, Fujii K, Kladwang W, Das R, Barna M. 2015. RNA regulons in Hox 5' UTRs confer ribosome specificity to gene regulation. Nature 517: 33-38. doi:10.1038/nature14010

Yanofsky C. 1981. Attenuation in the control of expression of bacterial operons. Nature 289: 751-758. doi:10.1038/289751a0

Zhang X, Bremer H. 1995. Control of the Escherichia coli rrnB P1 promoter strength by ppGpp. J Biol Chem 270: 11181-11189. doi:10 .1074/jbc.270.19.11181

Zhang J, Li D, Zhang J, Chen D, Murchie Al. 2017. Osmium tetroxide as a probe of RNA structure. RNA 23: 483-492. doi:10.1261/rna .057539 .116

Zuker M. 2003. Mfold web server for nucleic acid folding and hybridization prediction. Nucleic Acids Res 31: 3406-3415. doi:10.1093/ nar/gkg595 

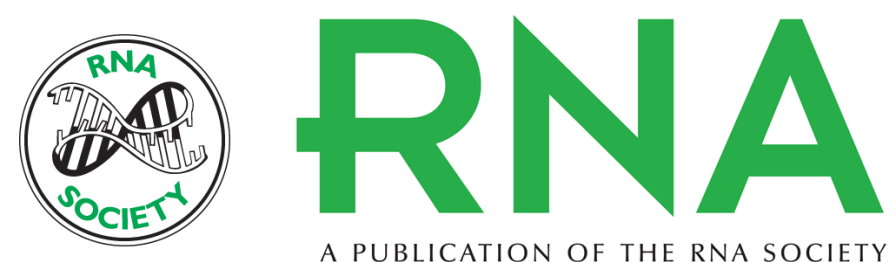

A PUBLICATION OF THE RNA SOCIETY

\section{Interactions between SAM and the $5^{\prime}$ UTR mRNA of the sam1 gene regulate translation in $S$. pombe}

Xuhui Zhang, Wenxia Sun, Dongrong Chen, et al.

RNA 2020 26: 150-161 originally published online November 25, 2019

Access the most recent version at doi:10.1261/rna.072983.119

\section{Supplemental http://rnajournal.cshlp.org/content/suppl/2019/11/25/rna.072983.119.DC1 Material}

References This article cites 59 articles, 16 of which can be accessed free at: http://rnajournal.cshlp.org/content/26/2/150.full.html\#ref-list-1

Creative This article is distributed exclusively by the RNA Society for the first 12 months after the Commons License full-issue publication date (see http://rnajournal.cshlp.org/site/misc/terms.xhtml). After 12 months, it is available under a Creative Commons License (Attribution-NonCommercial 4.0 International), as described at http://creativecommons.org/licenses/by-nc/4.0/.

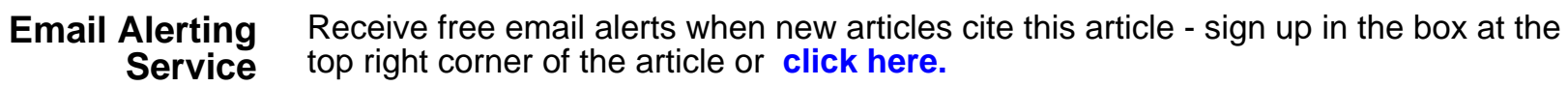

